Cardiothoracic Anesthesia, Respiration and Airway

\title{
A standardized multidisciplinary approach reduces the use of allogeneic blood products in patients undergoing cardiac surgery
}

[L'approche systématique et multidisciplinaire diminue le recours aux produits sanguins allogènes chez les malades opérés du coeur]

Philippe Van der Linden MD PhD, Stefan De Hert MD PhD, Anne Daper MD, Anne Trenchant MD, Daniel Jacobs MD, Corinne De Boelpaepe MD, Pierre Kimbimbi MD, Pierre Defrance MD, Gaëtan Simoens MD

Purpose: Individual and institutional practices remain an independent predictor factor for allogeneic blood transfusion. Application of a standardized multidisciplinary transfusion strategy should reduce the use of allogeneic blood transfusion in major surgical patients.

Methods: This prospective non randomized observational study evaluated the effects of a standardized multidisciplinary transfusion strategy on allogeneic blood products exposure in patients undergoing non-emergent cardiac surgery. The developed strategy involved a standardized blood conservation program and a multidisciplinary allogeneic blood transfusion policy based mainly on clinical judgement, not only on a specific hemoglobin concentration. Data obtained in a first group including patients operated from September 1997 to August 1998 (Group pre: $n=32$ I), when the transfusion strategy was progressively developed, were compared to those obtained in a second group, including patients operated from September 1998 to August 1999 (Group post: $n=3$ I 5) when the transfusion strategy was applied uniformly

Results: Patient populations and surgical procedures were similar. Patients in Group post underwent acute normovolemic hemodilution more frequently, had a higher core temperature at arrival in the intensive care unit and presented lower postoperative blood losses at day one. Three hundred forty units of packed red blood cells were transfused in 33\% of the patients in Group pre whereas 161 units were transfused in 18\% of the patients in Group post ( $P$ $<0.00$ I). Pre- and postoperative hemoglobin concentrations, mortality and morbidity were not different among groups.

Conclusion: Development of a standardized multidisciplinary transfusion strategy markedly reduced the exposure of cardiac surgery patients to allogeneic blood.
Objectif : La variabilité de la pratique transfusionnelle demeure un facteur prédictif indépendant de la transfusion sanguine allogénique. Le développement d'une politique transfusionnelle multidisciplinaire standardisée devrait réduire de manière significative l'utilisation de dérivés sanguins allogéniques des patients subissant une intervention chirurgicale lourde.

Méthode: Cette étude prospective non randomisée a évalué les effets d'une stratégie transfusionnelle multidisciplinaire standardisée sur l'exposition aux dérivés sanguins allogéniques de patients subissant une intervention en cardiochirurgie (exception faite des procédures de sauvetage). La stratégie développée repose sur un programme d'épargne sanguine standardisé et une approche transfusionnelle multidisciplinaire uniformisée basée non seulement sur le taux d'hémoglobine, mais aussi sur le jugement clinique. Les données obtenues chez tous les patients opérés entre septembre 1997 et août 1998 (Groupe I, n = 321; mise en place de la stratégie transfusionnelle) ont été comparées à celles obtenues chez les patients opérés dans les mêmes conditions entre septembre 1998 et août 1999 (Groupe II, $n=31$; stratégie transfusionnelle appliquée de manière uniforme).

Résultats : Les deux populations ainsi que le type d'intervention étaient comparables. Les patients du Groupe II ont bénéficié plus fréquemment d'une hémodilution normovolémique intentionnelle, sont arrivés aux soins intensifs avec une température corporelle plus élevée et présentaient, au premier jour postopératoire, des pertes sanguines moindres que les patients du Groupe I. Trois cent quarante unités de concentrés érythrocytaires ont été transfusées chez $33 \%$ des patients du Groupe I alors que 161 unités étaient transfusées chez $18 \%$ des patients du Groupe II $(P<0,00$ I). Les taux d'hémoglobine pré- et postopératoire, ainsi que la mortalité et la morbidité hospitalière étaient comparables dans les deux groupes.

From the Department of Cardiac Anaesthesia, CHU Charleroi, Jumet, Belgium.

Address correspondence to: Dr. Philippe Van der Linden, Department of Cardiac Anaesthesia, C.H.U. Charleroi, 73, route de Gosselies, B-6040 Jumet, Belgium. Phone: 3271 251 572; Fax: 3271251 583; E-mail: pvanderlinden@skynet.be

Accepted for publication April 19, 2001.

Revision accepted July 9, 2001. 
Conclusion : Le développement d'une approche transfusionnelle multidisciplinaire standardisée réduit de manière significative l'exposition aux dérivés sanguins allogéniques des patients en chirurgie cardiaque.

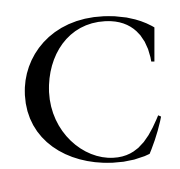

ARDIAC surgery still remains one of the major consumers of allogeneic blood products. ${ }^{1-3}$ Infectious risks of transfusion, but also cost and resource efficiency considerations have triggered continuing efforts to reduce blood transfusion. Despite different national consensus guidelines, several American and European multicenter studies demonstrated a substantial variability in perioperative transfusion practice. ${ }^{4-8}$ Even in a selected patient population at low risk for transfusion therapy, the percentage of patients transfused and the median number of units transfused per patient varied considerably between institutions. ${ }^{6}$ The SANGUIS study evaluated blood product use in 43 teaching hospitals from ten European countries, and found that transfusion rates depend more on physicians than on type of procedure, patient population or hospital. ${ }^{7}$ Similar results have been found in a more recent study involving teaching and non-teaching hospitals. ${ }^{8}$ Reviewing the appropriateness of red cell transfusion, based on a variety of criteria. Hébert et al. ${ }^{9}$ estimated that the proportion of unnecessary transfusions ranges from 4 to $66 \%$. Reasons for the large variability in transfusion practice remain elusive, but clinicians' practice and attitude may be entrenched and slow to change. ${ }^{10}$ The avoidance of unnecessary blood transfusion can be achieved by adopting a standardized blood conservation strategy, which will consequently reduce allogeneic blood use. The present study tested this hypothesis in patients undergoing non-emergent cardiac surgery.

\section{Materials and methods}

A multidisciplinary approach to blood conservation has been progressively developed by the department of cardiac anesthesia in our institution since September 1997. This strategy involves a standardized blood conservation program and allogeneic blood transfusion policy in the pre-, the intra- and the postoperative period.

\section{Preoperative period}

On admission, serum iron concentration was obtained in all patients, and oral iron therapy (ferrogluconate $695 \mathrm{mg} \cdot \mathrm{day}^{-1}$ ) administered whenever iron concentration was found to be below the normal range (65-175 $\left.\mu \mathrm{g} \cdot \mathrm{dL}^{-1}\right)$. Aspirin derivatives were continued until the day before surgery. In patients requiring preoperative anticoagulation, a continuous heparin infusion was administered up to the start of surgery.

\section{Intraoperative period}

Intentional normovolemic hemodilution was performed in all patients with a prebypass hematocrit greater than $33 \%$. The amount of blood collected was calculated in order to reach a hematocrit of $20 \%$ on cardiopulmonary bypass (CPB). Use of aprotinin (Trasylol, Bayer SA, Brussels, Belgium) was restricted to the following indications: a low red blood cell volume (below $1500 \mathrm{~mL}$ ), complex operations (coronary artery grafting and valve replacement, aortic reconstruction), and low preoperative platelet count $\left(<125,000 \cdot \mathrm{mm}^{3}\right)$. The Hammersmith regimen was used in all cases ( 2 million KIU as a bolus dose, followed by a continuous infusion of 500,000 KIU.hr-1 until the end of the operation, and 2 million KIU in the CPB prime). No other antifibrinolytic was administered. A cell saver device (Cell Saver 5, Haemonetics CO, Braintree, MA, USA) was used for redo operations and aortic reconstructions. Initial anticoagulation consisted of $400 \mathrm{IU} \cdot \mathrm{kg}^{-1}$ heparin. Additional doses were administered throughout $\mathrm{CPB}$ to maintain the activated clotting time always above $750 \mathrm{sec}$ (ACT II monitor, Medtronic BV, Kerkrade, The Netherlands).

The heart-lung machine was primed with one litre of $3.5 \%$ urea-linked gelatin (Haemaccel ${ }^{\circledR}$, Hoechst SA, Brussels, Belgium). Ultra-filtration was used in the presence of a high CPB volume. Packed red blood cells (PRBC) were added to the pump when the hematocrit was below $20 \%$, in the presence of a low CPB volume. All bypass procedures were performed under moderate hypothermia $\left(30-32^{\circ} \mathrm{C}\right)$, and the heart was arrested with cold crystalloid cardioplegic solution.

All patients were rewarmed to a bladder temperature $>36^{\circ} \mathrm{C}$ before separation from CPB. At the end of the procedure, reversal of heparin with protamine sulfate was titrated using the heparinase-activated clotting time (High Range Heparinase test cartridges, Medtronic BV, Kerkrade, The Netherlands). Blood from the bypass circuit was returned to all patients upon completion of the operation, after having retransfused the blood collected during normovolemic hemodilution.

Intraoperative blood loss was evaluated by measuring the volume of blood collected in the suction reservoirs and by calculating the weight change of the surgical sponges and drapes. This evaluation was performed twice, before and after the bypass procedure. 


\section{Postoperative period}

On arrival in the intensive care unit (ICU), patients were covered with a convection-air warming blanket. Before the standardized approach was developed, PRBC transfusion was guided only by the hemoglobin concentration, the threshold varying from one physician to another. After institution of the standardized approach, PRBC transfusion was guided by clinical judgement taking into account, not only the hemoglobin concentration, but also the physical status of the patient (age, estimated blood volume, cardiovascular and respiratory functions), and the extent of postoperative bleeding. Platelets and fresh frozen plasma were transfused in the presence of abnormal clinical bleeding, using the algorithm developed by Despotis et al., ${ }^{11}$ based on the platelet count, and prothrombin and partial thromboplastin times. On the ward, PRBC transfusion was also guided by clinical judgement when patients had a hemoglobin concentration between 70 and $100 \mathrm{~g} \cdot \mathrm{L}^{-1} \cdot 12$ Patients with a hemoglobin concentration above 100 g. $\mathrm{L}^{-1}$ were never transfused, while patients with a hemoglobin concentration below $70 \mathrm{~g} \cdot \mathrm{L}^{-1}$ were usually transfused. Oral iron therapy was instituted when hemoglobin concentration was below $90 \mathrm{~g} \cdot \mathrm{L}^{-1}$

Postoperative blood loss was evaluated by measuring the mediastinal chest tube drainage up to withdrawal of the drains.

\section{Data collection and analysis}

This study was approved by, and carried out, according to the instructions of our institutional Ethics Committee. All patients undergoing non-emergent cardiac surgery from September 1, 1997 to August 31, 1999 were included. Procedures consisted of coronary artery bypass graft surgery, single or multiple valve replacement, and complex aortic reconstruction. The effects of our standardized blood sparing strategy were evaluated with regard to allogeneic blood product exposure, and in-hospital postoperative morbidity and mortality. Data obtained in the first group included patients operated between September 1, 1997 and August 31, 1998 (Group pre: $n=321$ ), when the transfusion strategy was progressively discussed and developed. These data were compared to those obtained in a second group of patients operated between September 1,1998 and August 31, 1999 (Group post: $n=315$ ) when the transfusion strategy was applied uniformly.

Data were analyzed using analysis of variance, unpaired Student's $t$ test, and $\chi^{2}$ test where applicable. To examine whether drug, devices or a more restrictive approach to transfusions had an effect on the use of blood products, a multivariate logistic regression analysis with backward elimination $(P<0.05)$ was performed.
TABLE I Demographic data

\begin{tabular}{llll}
\hline & $\begin{array}{l}\text { Group pre } \\
n=321\end{array}$ & $\begin{array}{l}\text { Group post } \\
n=315\end{array}$ & $P$ \\
\hline Age (y) & $64 \pm 11$ & $65 \pm 12$ & 0.47 \\
Sex: male/female (\%) & $65 / 35$ & $69 / 31$ & 0.35 \\
BMI (kg-m ${ }^{-2}$ ) & $27.8 \pm 4.8$ & $27.7 \pm 4.6$ & 0.89 \\
Preoperative clinical risk score * & $3.7 \pm 2.9$ & $3.4 \pm 2.6$ & 0.26 \\
LVEF (\%) & $58 \pm 15$ & $60 \pm 15$ & 0.24 \\
AMI <6 weeks (\%) & 11 & 9 & 0.39 \\
Unstable angina (\%) & 25 & 20 & 0.12 \\
Hypertension (\%) & 47 & 52 & 0.15 \\
Diabetes (\%) & 16 & 21 & 0.28 \\
Renal insufficiency (\%) & 3 & 5 & 0.21 \\
Preoperative treatment & & & \\
B blockers (\%) & 63 & 65 & 0.67 \\
ACE inhibitors (\%) & 32 & 32 & 0.99 \\
$\quad$ Diuretics (\%) & 21 & 24 & 0.29 \\
Aspirin (\%) & 72 & 77 & $<0.01$ \\
$\quad$ Heparin (\%) & 26 & 27 & 0.10 \\
\hline
\end{tabular}

$\mathrm{BMI}=$ body mass index; $\mathrm{LVEF}=$ left ventricular ejection fraction; AMI=acute preoperative myocardial infarction.

*From reference \#13: Tuman KJ, McCarthy RJ, March RJ, Najafi $H$, Ivankovich $A D$. Morbidity and duration of ICU stay after cardiac surgery. A model for preoperative risk assessment. Chest 1992; 102: 36-44

A $P$ value $<0.05$ was considered significant. Data are expressed as mean \pm standard deviation.

\section{Results}

Demographic characteristics (Table I)

No significant differences were observed between groups with regard to age, sex, body mass index, and preoperative left ventricular ejection fraction. Preoperative risk assessed by a simplified clinical risk scoring system ${ }^{13}$ was similar in both groups. Incidence of preoperative aspirin treatment was significantly higher in Group post.

\section{Intraoperative data (Table II, Figure 1)}

A higher number of patients underwent acute normovolemic hemodilution in Group post (Figure 1). The amount of blood collected per patient was also significantly higher $(1300 \pm 573 \mathrm{~mL}$ in Group post $v s 1089 \pm$ $414 \mathrm{~mL}$ in Group pre; $P<0.01$ ). Aprotinin was administered with the same frequency in both groups. The cell saver was used more frequently in Group post. On the contrary, ultra-filtration was performed more frequently in Group pre. Type of surgery and operative priority had a similar distribution in both groups. Seven percent of the patients in the study group and $9 \%$ in the control group underwent redo-operations. Duration of $\mathrm{CPB}$ and aortic cross clamping were similar in both 
TABLE II Intraoperative data

\begin{tabular}{llll}
\hline & $\begin{array}{l}\text { Group pre } \\
n=321\end{array}$ & $\begin{array}{l}\text { Group post } \\
n=315\end{array}$ & $P$ \\
\hline $\begin{array}{l}\text { Type of surgery } \\
\text { CABG (\%) }\end{array}$ & 69 & 76 & 0.12 \\
Valvular (\%) & 10 & 9 & \\
Complex (\%) & 21 & 15 & \\
Operative priority & & & 0.80 \\
Urgent (\%) & 7 & 6 & \\
Elective (\%) & 93 & 94 & 0.28 \\
Redo operations & 9 & 7 & 0.43 \\
Duration of CPB (min) & $111 \pm 32$ & $113 \pm 34$ & $88 \pm 26$ \\
Aortic clamp (min) & $86 \pm 24$ & 88.53 \\
Blood loss (mL) & $332 \pm 264$ & $314 \pm 214$ & 0.34 \\
\hline
\end{tabular}

$\mathrm{CABG}=$ coronary artery bypass grafting; $\mathrm{CPB}=$ cardiopulmonary bypass.

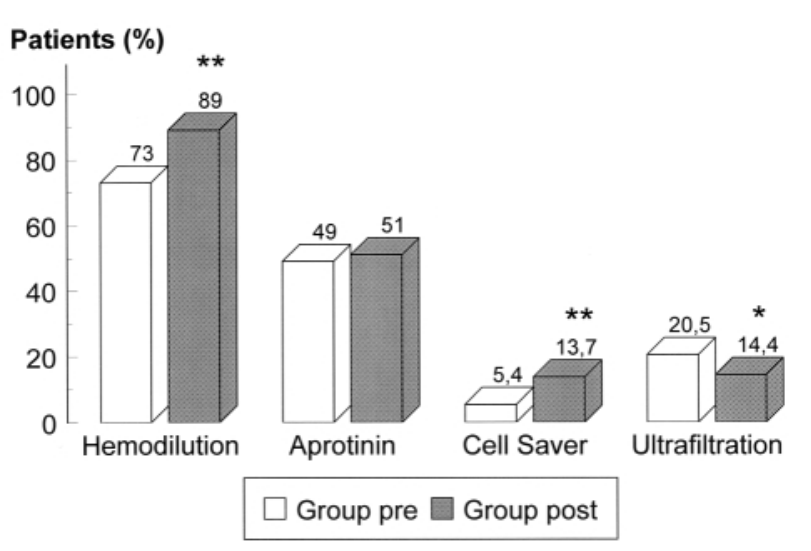

FIGURE 1 Blood conservation program in the two groups of patients. Open bars: Group pre; crossed bars: Group post. ${ }^{*} P$ $<0.05 ;{ }^{* *} P<0.01$ vs Group pre.

groups. Perioperative blood losses were not different between groups.

Postoperative data (Table III)

In Group post, patients' temperature on arrival in the ICU was higher, and immediate and first day postoperative blood losses significantly lower than in Group pre. In-hospital mortality and length of stay were similar in both groups. Postoperative complications were not different between groups.

Allogeneic transfusions (Table IV, Figures 2 and 3) One hundred sixty-one units of PRBC were transfused in 57 patients in Group post, whereas 340 units were
TABLE III Postoperative data

\begin{tabular}{llll}
\hline & $\begin{array}{l}\text { Group pre } \\
n=321\end{array}$ & $\begin{array}{l}\text { Group post } \\
n=315\end{array}$ & $P$ \\
\hline ICU temperature $\left({ }^{\circ} \mathrm{C}\right)$ & $35.3 \pm 0.7$ & $35.9 \pm 0.6$ & $<0.01$ \\
Blood loss on arrival in ICU & & & $<0.01$ \\
$<100 \mathrm{~mL}$ & 50 & 64 & \\
$100-300 \mathrm{~mL}$ & 43 & 33 & \\
$>300 \mathrm{~mL}$ & 7 & 3 & \\
Reoperation for hemorrhage $(\%)$ & 3.1 & 2.5 & 0.66 \\
Blood loss of postop day one (mL) $621 \pm 457$ & $532 \pm 369$ & $<0.01$ \\
In hospital death (\%) & 4.7 & 3.8 & 0.59 \\
ICU L.O.S. (days) & $2.6 \pm 4.2$ & $2.7 \pm 3.6$ & 0.97 \\
Hospital L.O.S. (days) & $10.6 \pm 8.4$ & $10.3 \pm 6.2$ & 0.64 \\
AMI (CKMB $\left.>100 \mathrm{IU} \cdot \mathrm{mL}^{-1}\right)(\%)$ & 7.8 & 9.2 & 0.52 \\
Respiratory problems $(\%)$ & 14.3 & 12.1 & 0.41 \\
Wound infections $(\%)$ & 2.5 & 3.2 & 0.61 \\
Neurologic deficit $(\%)$ & 1.9 & 1.6 & 0.34 \\
Hemodialysis $(\%)$ & 4.4 & 3.2 & 0.46 \\
\hline
\end{tabular}

Hemodialysis (\%)

ICU=intensive care unit; L.O.S.=length of stay; AMI=acute myocardial infarction.

transfused in 108 patients in Group pre $(P<0.001)$. Figure 2 displays the distribution of the units of PRBC transfused among patients in both groups. The decrease in blood exposure in the study group was essentially related to the lower frequency of transfusion on postoperative day one, in the ICU and on postoperative days two through seven on the ward (Table IV). Hemoglobin concentration preoperatively and postoperatively at days one, two, five and at discharge did not differ among groups (Figure 3 ). However, the number of patients with a hemoglobin concentration below $90 \mathrm{~g} \cdot \mathrm{L}^{-1}$ at discharge was significantly higher in Group post (19.7 vs 13.7\% in Group pre: $P<0.05$ )

Fifty-four units of fresh frozen plasma were transfused in 15 patients in Group post, whereas 145 units were transfused in 28 patients Group pre $(P=0.011)$.

This reduction was essentially related to the lower frequency of transfusion on postoperative day one, in the ICU (Table IV). Platelet transfusion rate was low and not different between groups.

The multivariate logistic regression analysis revealed that the number of reoperations, the preoperative hemoglobin concentration, the temperature at arrival in the ICU, and the use of preoperative hemodilution and cell saver device were significantly different between the two groups. After adjustment for these different factors, red blood cell transfusion remained significantly lower in Group post than in Group pre (adjusted odds ratio $0.261 ; 95 \%$ confidence intervals 0.158-0.431, $P<0.0001$ ) 
TABLE IV Allogenic transfusions (\% patients transfused)

\begin{tabular}{llllll}
\hline & & Intraop & Postop day 1 & Postop days 2-7 & Total \\
\hline Packed red blood cells & Group pre & 5.6 & 18 & & \\
& Group post & 3.2 & 93 & $13^{* *}$ & $18^{* * *}$ \\
Fresh frozen plasma & Group pre & 0.3 & 7.8 & 1.9 & 8.7 \\
& Group post & 0.6 & $3.5^{*}$ & 0.6 & $4.8^{*}$ \\
Platelets & Group pre & 0.9 & 1.6 & 0.6 & 2.5 \\
& Group post & 1.3 & 2.5 & 0.6 & 3.5 \\
\hline
\end{tabular}

${ }^{*} P<0.05 ;{ }^{* *} P<0.01 ;{ }^{* *} P<0.001$ vs group pre.

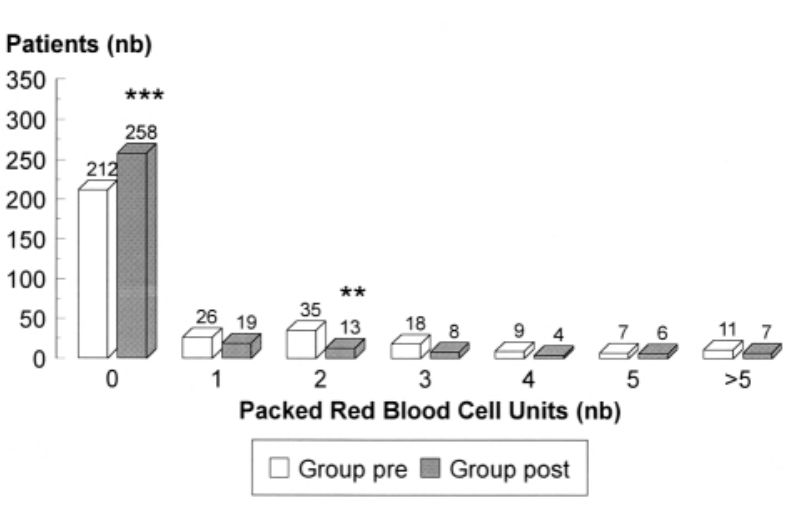

FIGURE 2 Total allogeneic blood exposure in the two populations. Open bars: Group pre; crossed bars: Group post. ${ }^{*} P$ $<0.01,{ }^{* *} P<0.001$ vs Group pre.

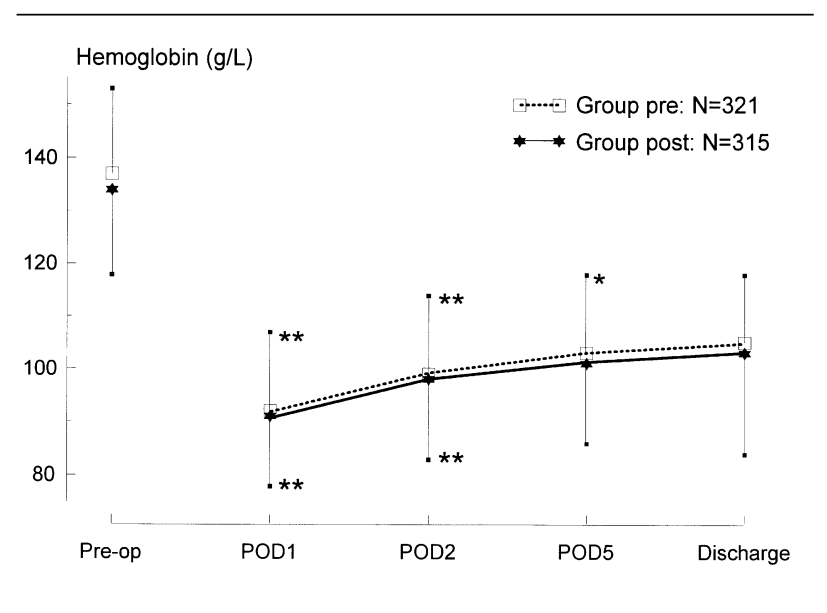

FIGURE 3 Pre- and postoperative hemoglobin concentrations in the two groups of patients. Open squares, dotted line: Group pre; Closed stars, solid line: Group post. ${ }^{*} P<0.05,{ }^{*}{ }^{*} P<0.01$ vs previous measurement. Pre op: preoperative; POD: postoperative day.

\section{Discussion}

The application of a standardized multidisciplinary blood conservation strategy markedly decreased allogeneic blood exposure in patients undergoing nonemergent cardiac surgery. This effect was essentially related to a reduction in allogeneic blood product use in the ICU and on the ward. This result was obtained without any increase in early postoperative morbidity or mortality. The developed strategy involved first, a rigorous blood conservation program aimed at decreasing perioperative blood loss and second, a standardized blood transfusion practice shared by anesthesiologists, ICU physicians and cardiac surgeons.

The blood conservation program

This program, directed toward minimizing bleeding in the intraoperative period, resulted in significant changes in our practice. The capacity of acute normovolemic hemodilution to reduce perioperative allogeneic transfusion remains controversial. ${ }^{14}$ However, several studies tend to demonstrate its efficacy after cardiac surgery. ${ }^{14-16}$ This technique constituted a major component of our intraoperative blood conservation program. Both the number of patients and the volume of blood collected were increased.

The efficacy of intraoperative cell salvage techniques and ultra-filtration remain controversial in cardiac surgery. ${ }^{17,18}$ Therefore, their use was restricted to very specific situations associated with expected high blood losses or a high priming volume. Although the cell saver was used more frequently and ultra-filtration less so, these techniques were employed in only $20 \%$ of the patients. Lowering the CPB prime volume as an additional component of an integrated blood conservation strategy has been shown to reduce the use of allogeneic blood products. ${ }^{19}$ In all our patients, a low CPB prime volume (with a maximum of $1000 \mathrm{~mL}$ ) was used.

The efficacy of aprotinin to minimize exposure to allogeneic blood in cardiac surgery has been widely demonstrated. ${ }^{20,21}$ However, this drug is associated with 
several side effects that should be taken into account ${ }^{22,23}$ Aprotinin was administered in about $50 \%$ of patients using the Hammersmith regimen as it appears to be the most effective and also the safer one. ${ }^{24,25}$

Hypothermia has been shown to significantly increase postoperative blood loss, probably by impairing platelet function and reducing clotting factor function. ${ }^{26}$ Rewarming after bypass was more vigorous in Group post patients who had a higher core temperature on arrival in the ICU. Interestingly, these patients exhibited lower postoperative blood losses than those in Group pre. Postoperative blood loss at day one was also significantly lower in Group post patients.

In the present study, aspirin was continued until the day of surgery, as it can reduce the incidence of myocardial infarction in coronary artery disease patients and improve graft patency. ${ }^{27}$ This strategy represents a difference with other reports where aspirin was discontinued because of a possible increase in hemorrhagic risk. ${ }^{15,28}$ It should be noted, however, that several studies using strict transfusion criteria have demonstrated that preoperative aspirin does not increase allogeneic transfusion in elective primary or reoperative coronary artery surgery. ${ }^{29,30}$

\section{Standardized transfusion practice}

There is increasing evidence that postoperative blood transfusion should be guided by clinical indications and not only by specific hematocrit or hemoglobin values. ${ }^{1,4,31-33}$ In the present study, the use of clinical judgement as the main transfusion trigger resulted in a $50 \%$ decrease in allogeneic blood utilisation. The number of transfused patients decreased significantly, whereas mean postoperative hemoglobin concentrations were similar in both groups. Several factors may have contributed to this observation. Immediate postoperative blood loss was significantly lower in the study group. However, the observed reduction cannot by itself fully explain the marked decrease in allogeneic blood transfusion. The use of a more aggressive intentional preoperative hemodilution strategy might also have resulted in a decreased net red blood cell mass loss (not measured in our study). Another possible explanation may be related to the reduced life span of transfused red blood cells, which are old when compared to the patient's circulating red cells. ${ }^{34,35}$ Whatever the exact reasons, our results emphasize the concept that a perioperative transfusion protocol cannot be based solely on hemoglobin concentrations. The reduction in allogeneic blood transfusion was mainly related to a decreased transfusion rate during the postoperative period on the ICU and on the ward. This observation stresses the importance of involving
ICU physicians and surgeons in any perioperative blood transfusion strategy.

Transfusion of fresh frozen plasma was significantly reduced in our study, especially in the early postoperative period. These results are in accordance with previous studies demonstrating that hemostatic blood product requirement is significantly reduced by the use of a transfusion algorithm based on coagulation testing. ${ }^{11,36}$

Finally, the marked reduction in allogeneic blood transfusion did not seem to be associated with any increase in postoperative morbidity or mortality, as already observed in other studies. ${ }^{1,15,33}$

The lack of randomization represents a limitation of our study. For obvious clinical reasons, patients were not randomly assigned to one of the two groups. Therefore time-dependent factors such as surgical technique or patient populations might have influenced the results. However, in both groups, patients were operated by the same surgeons, using the same techniques and the time period was relatively short. Based on available patient data, both groups appeared similar. A multivariate logistic regression analysis with backward elimination was performed to define the variables that were significantly different between the two groups. After adjustment for theses variables, red blood cell transfusion still remained significantly lower in Group post.

In conclusion, a standardized multidisciplinary approach to blood conservation in cardiac surgery decreases bleeding and transfusion requirements in a safe and cost-effective manner. In view of these results, it seems reasonable to suggest that the true efficacy of any novel blood conservation technique can only be evaluated when an institutional multidisciplinary approach to blood transfusion has been achieved already.

\section{References}

1 Johnson RG, Thurer RL, Kruskall MS, et al.

Comparison of two transfusion strategies after elective operations for myocardial revascularization. J Thorac Cardiovasc Surg 1992; 104: 307-14

2 Goodnough LT, Johnston MFM, Toy PTCY. The variability of transfusion practice in coronary artery bypass surgery. JAMA 1991; 265: 86-90.

3 Kytölä L, Nuutinen L, Myllyla G. Transfusion policies in coronary artery bypass - a nationwide survey in Finland. Acta Anaesthesiol Scand 1998; 42: 178-83.

4 Goodnough LT, Despotis GJ, Hogue CW, Ferguson TB Jr. On the need for improved transfusion indicators in cardiac surgery. Ann Thorac Surg 1995; 60: 473-80.

5 Surgenor DM, Churchill WH, Wallace EL, et al. The specific hospital significantly affects red cell and com- 
ponent transfusion practice in coronary artery bypass graft surgery: a study of five hospitals. Transfusion 1998; 38: 122-34.

6 Stover EP, Siegel LC, Parks R, et al. Variability in transfusion practice for coronary artery bypass surgery persists despite national consensus guidelines.

Anesthesiology 1998; 88: 327-33.

7 Sirchia G, Giovanetti AM, McClelland B, Fracchia GN Safe and good use of blood in surgery (SANGUIS).

Use of blood products and artificial colloids in 43 European hospitals. European Commission, European Community, Brussels: 1994.

8 Baele P, Beguin C, Waterloos H, et al. The Belgium BIOMED Study about transfusion for surgery. Acta Anaesth Belg 1998; 49: 243-303.

9 Hébert PC, Schweitzer I, Calder L, Blajchman M, Giulivi A. Review of the clinical practice literature on allogeneic red cell transfusion. Can Med Assoc J 1997; 156 (1lsuppl): 9-26.

10 Salem-Schatz SR, Aworn J, Soumerai SB. Influence of clinical knowledge, organizational context, and practice style on transfusion decision making. Implications for practice change strategies. JAMA 1990; 264: 476-83.

11 Despotis GJ, Santoro SA, Spitznagel E, et al. Prospective evaluation and clinical utility of on-site monitoring of coagulation in patients undergoing cardiac operation. J Thorac Cardiovasc Surg 1994; 107: 271-9.

12 Janvier $G$, Annat $G$. Are there limits to haemodilution? Ann Fr Anesth Reanim 1995; 14(Suppl. I): 9-20.

13 Tuman KJ, McCarthy RJ, March RJ, Najafi $H$, Ivankovich $A D$. Morbidity and duration of ICU stay after cardiac surgery. A model for preoperative risk assessment. Chest 1992; 102: 36-44.

14 Bryson GL, Laupacis A, Wells GA. Does acute normovolemic hemodilution reduce perioperative allogeneic transfusion? A meta-analysis. Anesth Analg 1998; 86 9-15.

15 Schönberger JPAM, Bredée JJ, Tjian D, Everts PAM, Wildevuur CRH. Intraoperative predonation contributes to blood saving. Ann Thorac Surg 1993; 56 893-8.

16 Helm RE, Rosengart TK, Gomez M, et al.

Comprehensive multimodality blood conservation: 100 consecutive CABG operations without transfusion. Ann Thorac Surg 1998; 65: 125-36.

17 Ferraris VA, Ferraris SP. Limiting excessive postoperative blood transfusion after cardiac procedures. Tex Heart Inst J 1995; 22: 216-30.

18 Goodnough LT, Brecher ME, Kanter MH, AuBuchon JP. Transfusion medicine. Second of two parts. Blood transfusion. N Engl J Med 1999; 340: 525-33.

19 Shapira OM, Aldea GS, Treanor PR, et al. Reduction of allogeneic blood transfusions after open heart opera- tions by lowering cardiopulmonary bypass prime volume. Ann Thorac Surg 1998; 65: 724-30.

20 Laupacis A, Fergusson D. Drugs to minimize perioperative blood loss in cardiac surgery: meta-analyses using perioperative blood transfusion as the outcome. Anesth Analg 1997; 85: 1258-67.

21 Levy $M$, Crombeecke $M E$, de Jonge E, et al.

Pharmacological strategies to decrease excessive blood loss in cardiac surgery: a meta-analysis of clinically relevant endpoints. Lancet 1999; 354: 1940-7.

22 Dietrich W, Späth P, Ebell A, Richter JA. Prevalence of anaphylactic reactions to aprotinin: analysis of two hundred forty-eight reexposures to aprotinin in heart operations. J Thorac Cardiovasc Surg 1997; 113: 194-201.

23 Alderman EL, Levy JH, Rich JB, et al. Analysis of coronary graft patency after aprotinin use: results from the international multicenter aprotinin graft patency experience (IMAGE) trial. J Thorac Cardiovasc Surg 1998 116: 716-30

24 Smith PK, Mublbaier LH. Aprotinin: safe and effective only with the full-dose regimen. Ann Thorac Surg 1996; 62: 1575-7.

25 Dietrich W, Schöpf K, Spannagl M, Jochum M, Braun $S L$, Meisner $H$. Influence of high- and low-dose aprotinin on activation of hemostasis in open heart operations. Ann Thorac Surg 1998; 65: 70-8

26 Schmied H, Kurz A, Sessler DI, Kozek S, Reiter A. Mild hypothermia increases blood loss and transfusion requirements during total hip arthroplasty. Lancet 1996; 347: 289-92.

27 Willard JE, Lange RA, Hillis LD. The use of aspirin in ischemic heart disease. N Engl J Med 1992; 327 175-81.

28 Sethi GK, Copeland JG, Goldman S, Moritz T, Zadina $K$, Henderson WG. Implications of preoperative administration of aspirin in patients undergoing coronary artery bypass grafting. J Am Coll Cardiol 1990; 15: 15-20.

29 Reich DL, Patel GC, Vela-Cantos F, Bodian C Lansman $S$. Aspirin does not increase homologous blood requirements in elective coronary bypass surgery. Anesth Analg 1994; 79: 4-8.

30 Tuman KJ, McCarthy RJ, O'Connor CJ, McCarthy $W E$, Ivankovich $A D$. Aspirin does not increase allogeneic blood transfusion in reoperative coronary artery surgery. Anesth Analg 1996; 83: 1178-84.

31 Spiess BD, Ley $C$, Body SC, et al. Hematocrit value on intensive care unit entry influences the frequency of $Q$ wave myocardial infarction after coronary artery bypas grafting. J Thorac Cardiovasc Surg 1998; 116: 460-7.

32 Bracey $A W$, Radovancevic R, Riggs $S A$, et al. Lowering the hemoglobin threshold for transfusion in coronary 
artery bypass procedures: effect on patient outcome

Transfusion 1999; 39: 1070-7.

33 Paone G, Silverman NA. The paradox of on-bypass

transfusion thresholds in blood conservation.

Circulation 1997; 96(suppl II): II205-9.

34 Schmidt H, Kongsgaard UE, Geiran O, Brosstad F.

Autotransfusion after open heart surgery: quality of shed mediastinal blood compared to banked blood.

Acta Anaesthesiol Scand 1995; 39: 1062-5.

35 Schmidt H, Lund JO, Nielsen SL. Autotransfused shed mediastinal blood has normal erythrocyte survival. Ann Thorac Surg 1996; 62: 105-8.

36 Shore-Lesserson L, Manspeizer HE, DePerio M, Francis $S$, Vela-Cantos F, Ergin MA. Thromboelastography- guided transfusion algorithm reduces transfusions in complex cardiac surgery. Anesth Analg 1999; 88: 312-9. 